\title{
Natural radioactivity and radon exhalation rate of Sardinian dimension stones
}

\author{
Valentina Dentoni $^{\mathrm{a}}$, Stefania Da Pelo ${ }^{\mathrm{b}, *}$, Mirsina Mousavi Aghdam ${ }^{\mathrm{a}}$, Paolo Randaccio ${ }^{\mathrm{g}}$, Alfredo Loi $^{\mathrm{b}}$, \\ Nicola Careddu ${ }^{\mathrm{a}}$, Alessandra Bernardini ${ }^{\mathrm{g}}$ \\ ${ }^{a}$ University of Cagliari, Department of Civil and Environmental Engineering and Architecture, Via Marengo 2, 09123 Cagliari, Italy \\ ${ }^{\mathrm{b}}$ University of Cagliari, Department of Chemical and Geological Sciences, University Campus of Monserrato, SP 8, $\mathrm{km} 0.700,09042 \mathrm{Monserrato}$ CA, Italy \\ ${ }^{\mathrm{g}}$ University of Cagliari, Department of Physics, University Campus of Monserrato, SP 8, km 0.700, 09042 Monserrato CA, Italy
}

\section{ARTICLE INFO}

\section{Article history:}

Received 11 August 2019

Received in revised form 12 January 2020

Accepted 6 Febraury 2020

Available online xxx

\section{Keywords}

Sardinian dimension stones

Natural radioactivity

Indoor radon level

Radon gas exposure

Activity concentration index

\begin{abstract}
A B S T R A C T
Due to the ever-growing public concern about radon risk arising from building materials, the radon exhalation rates and the natural radioactivity of eighteen dimension stones mostly used in Sardinia and widely exported worldwide have been estimated by means of laboratory tests. Some of the quarrying companies that operate within the Sardinian territory provided the samples to be tested, which include twelve granitoids, four pyroclastic rocks and two basalts. The Activity Concentration Index $\left(\mathrm{I}_{\gamma}\right)$, the External Radiation Hazard Index $\left(\mathrm{H}_{\mathrm{ex}}\right)$ and the Radium equivalent activity $\left(\mathrm{Ra}_{\mathrm{eq}}\right)$ were calculated for each rock sample under investigation, based on the estimated values of ${ }^{222} \mathrm{Rn}$ exhalation rate and ${ }^{226} \mathrm{Ra},{ }^{232} \mathrm{Th}$ and ${ }^{40} \mathrm{~K}$ radioactivity concentration. A poor correlation between radon release rates and ${ }^{226} \mathrm{Ra}$ radioactivity concentrations was found. The contribution to indoor radon accumulation was also simulated for the stone with the highest ${ }^{222} \mathrm{Rn}$ exhalation rate and the resulting concentration compared with the limit value establish by the 2013/59/Euratom Directive. These findings can be extended to rocks formed in similar geodynamic settings that are likely to produce igneous rocks with similar petrographic and geochemical features.
\end{abstract}

(C) 2020

\section{Introduction}

Prolonged exposure to radon gas $\left({ }^{222} \mathrm{Rn}\right)$, which is known as the main contributor to the overall natural radiation dose absorbed by population, may increase the risk of developing lung cancer [1]. The main source of indoor radon is the pressure-driven influx from subsurface soil, though building materials with high concentration of Radium $\left({ }^{226} \mathrm{Ra}\right)$ may represent another significant font of natural radiation [2]. Radon $\left({ }^{222} \mathrm{Rn}\right)$ is in fact the decay product of radium $\left({ }^{226} \mathrm{Ra}\right)$ and a member of the Uranium $\left({ }^{238} \mathrm{U}\right)$ decay chain. Traces of Uranium/Radium can be found in different rock types, with concentrations from 2-5 ppm (background) up to $1000 \mathrm{ppm}$ (black shales). As regards igneous rocks, in particular, the occurrence of uranium is more common in crystalline rocks, like granites, granitic pegmatites and syenites [3]. Uranium/radium content in those rocks is mainly incorporated into accessory minerals, such as monazite, allanite, sphene, and zircon [4].

Although measurements of U/Ra activity can provide useful information about radon release potential, the exhalation of Radon $\left({ }^{222} \mathrm{Rn}\right)$ from a given rock surface is strongly influenced by the petrographic and petro-physical characteristics of the rock itself (i.e.: micro-fissures, grain size, arrangement, alteration degree and contact surfaces between constituents) [3]. Therefore, real-time measurements of ${ }^{222} \mathrm{Rn}$ exhalation rates need to be performed in order

\footnotetext{
* Corresponding author.

E-mail addresses: vdentoni@unica.it (V. Dentoni); sdapelo@unica.it (S. Da Pelo); mirsina.aghdam@unica.it (M. Mousavi Aghdam); paolo.randaccio@ca.infn.it (P. Randaccio); alfloi@unica.it (A. Loi); ncareddu@unica.it (N. Careddu); alessandra. bernardini@dsf.unica.it (A. Bernardini)
}

to estimate the actual risk associated to a given natural stone [5]. Those measurements must be performed on samples in the form of blocks or slabs, as grounding the rock increases the specific surface and decreases the grain size, thus producing an overestimation of the radon exhalation rate and consequently a false alarm about the actual risk associated to the material under investigation [6].

The article discusses the results of the experimental tests carried out on eighteen Sardinian dimension stones, which were aimed at estimating their natural radioactivity and the potential for radon emission. All samples considered in the study were provided by quarrying companies that operate in Sardinia and include twelve granites (Rosa Beta to Grigio Majore), two basalts (Basalto Rosso Vino and Basalto Sardo) and four pyroclastic rocks (Pietra di Serrenti to Porfido Rosso di Arbatax).

Three criteria were taken into account for the selection of the rocks to be investigated: i) to be commonly available in the market; ii) to belong to those categories of rocks that are believed to pose a higher risk, according to the results of former studies $[2,5,7]$; iii) to be representative of different geological settings related to different commonly widespread geodynamic environments.

It is worth highlighting as the use of the natural stones under investigation is testified since prehistoric age by many examples of engineering and architectural works, both in private dwellings and public buildings, throughout the Sardinian territory. Entire villages in Sardinia were built with boulders of natural stones provided by the quarries operating nearby. Nowadays, the use of the same natural stones, which have been recently categorized as Global Natural Heritage Stone Resources (GHSE) [8,9], has become essential for the restoration of those historical constructions, while many touristic locations along the coastline have been recently built with the same stones to recall the Sardin- 
ian heritage resources. The wide use of the construction material under investigation, which is not strictly related to ornamental purposes, highlights the relevance of the risk evaluation hereby discussed.

\section{Material and methods}

\subsection{Geological and petrographic characteristics of the tested samples}

The most important dimension stones extracted in Sardinia are granites, limestone, basalt and pyroclastic stones (generally marketed as trachyte, without distinction). Granites and limestones are mainly quarried in central-eastern and north-eastern Sardinia, while the extraction sites of basalts and pyroclastic rocks are widespread in a large portion of central-western Sardinia [10].

In Sardinia, outcropping rocks give evidence of geological global events that occurred over periods dating back from Cambrian to Quaternary. Rocks belonging to the Paleozoic Era cover about half of the island surface $\left(13,000\right.$ out of $\left.24,000 \mathrm{~km}^{2}\right)$ [11].

Granites constitute the calcalkaline plutonic complex, extended for about $6,000 \mathrm{~km}^{2}$ [12]. This outcrop is a sequence of Corsican- Sardinian batholite, which is closely related to the evolution of the south European Variscan belt [13]. The Sardinian batholite consists mainly of monzogranites (65\%) and, subordinately, leucogranites, tonalites and granodiorites (34\%). Gabbroic masses are scarce and crop out mainly in the south of Sardinia [14]. Zircon is probably the main ${ }^{238} \mathrm{U}$ and ${ }^{232} \mathrm{Th}$ bearing mineral in the less evolved granites (such as Rosa Beta and Grigio Malaga), while Y-bearing phases, such as allanite and xenotime, become progressively more important during the evolution of magmas [14].

Pyroclastic rocks and basalts are linked to the geodynamic evolution of the Mediterranean area, which led to an intense volcanism coeval or alternated to the deposition of marine and continental sediments of the transgressive and regressive phases that occurred between the Middle Eocene and the Miocene. The formers are related to two main geological events: the west-dipping subduction of the Adria plate, which gave a calcalkaline volcanic cycle in the Oligocene-Miocene represented by prevailing andesitic suites, and the opening of the Algero-Provençal and North Tyrrhenian basins associated with a volcanism from calcalkaline o peralcaline, with prevailing riodacitic suites. The basalts are related to the extensional tectonics that affected in the Pliocene the south-Tyrrhenian area following the opening of the S-Tyrrhenian Basin. Continental and (rare) marine deposits were covered and partially interlayered with interpolate basaltic lava flows, alkaline, transitional and sub-alkaline volcanic cycle [11].

The experimental tests discussed in this study were carried out on the eighteen dimension stones represented in Fig. 1, which belong to different geodynamic settings. The granitic samples represent a Palaeozoic crust formed in a collisional orogen; the calc-alkaline pyroclastic rocks were emplaced in a continental volcanic arc related to a Cenozoic subduction, and finally basaltic lava flow emplaced in an anorogenic setting. Table 1 summarizes the main features and the provenance of each investigated rock sample $[8,9,14,15]$. A simplified geological map of Sardinia with the location of the main quarries that exploit the dimension stones under investigation is reported in Fig. 2. The main geochemical features of the tested rocks are reported in Primavori [15]. The activity concentration of radionuclides in those rocks varies from about $10 \mathrm{~Bq} \mathrm{~kg}-1$ of ${ }^{226} \mathrm{Ra}$ in basalts to $1180 \mathrm{~Bq} \mathrm{~kg}{ }^{-1}$ of ${ }^{40} \mathrm{~K}$ in granites. Table 2 reports the mean values and the standard deviation of the activity concentration of ${ }^{226} \mathrm{Ra},{ }^{232} \mathrm{Th},{ }^{40} \mathrm{~K}$ determined for the same lithotypes tested in this study [14-16].

\subsection{Measurement of radon exhalation rates}

Direct measurements of radon exhalation rates were performed on rock slabs about 3-4 cm thick, with sides between 9 and $21 \mathrm{~cm}$ and total emitting surface from 490 to $2100 \mathrm{~cm}^{2}$. The volume and porosity were estimated for all samples according to ISRM [17]. Each sample was first polished and then enclosed in a 10.4-liter closed chamber, together with a real-time radon-monitoring instrument (Radex MR-107), which measures the radon activity growth over time $[5,18,19]$. According to Leonardi et al. [18], the dynamic method was applied in order to overcome problems of chamber leakages, since the chamber was not perfectly airtight. Radon concentration, temperature and relative humidity inside the chamber were registered each hour, for an overall test duration of about $120 \mathrm{~h}$. The radon activity concentration inside the sealed chamber is described by the two-dimensional diffusion theory [20]. Considering both the back diffusion and the radon leakage, the following formula is used to express the variability of the radon concentration over time:

$\mathrm{C}_{(\mathrm{t})}=\mathrm{C}_{0} e^{-t \lambda_{\mathrm{c}}}+\mathrm{C}_{\mathrm{m}}\left(1-e^{-t \lambda_{\mathrm{c}}}\right)$

where $\lambda_{\mathrm{e}}$ is the effective radon decay constant $\left(\mathrm{h}^{-1}\right)$, which accounts for the radon decay, the leak rate of the system and the back diffusion; $\mathrm{C}_{0}$ and $\mathrm{C}_{\mathrm{m}}$ are the radon activity concentration $\left(\mathrm{Bq} \mathrm{m} \mathrm{m}^{-3}\right)$ at time $=0$ and its maximum value respectively [18]. As shown in Fig. 3 for Rosa Limbara, the activity growth was modeled for all samples by using the nonlinear least squares fitting of the experimental data with Eq. (2) [20-22]. The resulting parameters $\lambda_{\mathrm{e}}$ and $\mathrm{C}_{\mathrm{m}}$ allowed the calculation of the exhalation rate $\left(E_{R n}\right)$, according to Eq. (3) [23]:

$\mathrm{E}_{\mathrm{Rn}}=\mathrm{C}_{\mathrm{m}} \lambda_{\mathrm{e}} \mathrm{V}_{\mathrm{eff}} / S\left[B q m^{-2} h^{-1}\right]$

where $V_{\text {eff }}$ is the effective volume of the calibration container $\left(\mathrm{m}^{3}\right)$ and $\mathrm{S}$ is the sample's total surface area $\left(\mathrm{m}^{2}\right)$ [18]. The radon exhalation rates were determined for all samples under exam, according to the procedure above described.

\subsection{Measurement of radionuclide activity concentrations}

In order to perform the measurements of radionuclide activity concentration, a small part of each sample was crushed and grounded to fine powder to obtain the same grain size, shape and similar mass and volume as the reference samples, providing similar detection efficiency. About $100 \mathrm{gr}$ (accuracy $\pm 0.01 \mathrm{~g}$ ) of powdered sample, with grain size less than $1 \mathrm{~mm}$, were separated and oven-dried. The $100 \mathrm{gr}$ sub-samples were placed inside cylindrical polyethylene containers, sealed and left undisturbed for four weeks, in order to reach the radioactive equilibrium between radon and its progenies. The activity concentrations of ${ }^{226} \mathrm{Ra},{ }^{232} \mathrm{Th}$ and ${ }^{40} \mathrm{~K}$ were analyzed by means of gamma-ray spectrometry performed with a 1024 channels $\mathrm{NaI}(\mathrm{Tl})$ scintillation detector ( $3 \times 3$ in.), which was protected from background radiation with a lead shield. The acquisition of the spectra was carried out using the Ortec MAESTRO software. Radioactive sources of ${ }^{137} \mathrm{Cs}$ and ${ }^{60} \mathrm{Co}$ were used for energy calibration. The activity of each reference radioactive source was known, making the efficiency calibration dispensable. The energy resolution was calculated to be $10.36 \%$, with reference to the full width of the peak at half of the maximum count level of $661 \mathrm{keV}$ photopeak for the ${ }^{137} \mathrm{Cs}$ source. Three reference samples of Uranium, Thorium and Potassium were prepared using IAEA (International Atomic Energy Agency) sources and a Potassium salt of acknowledged chemical composition. The spectrum of each analysed sample was obtained as the weighed sum of the three spectra ${ }^{226} \mathrm{Ra},{ }^{232} \mathrm{Th}$ and ${ }^{40} \mathrm{~K}$, plus the background spectrum; the weight of each spectrum depending on the mass (i.e.: the activity) of the radioisotope in the sample under analysis. The specific activity of samples was estimated according to the maximum likelihood algorithm [24]. The variance reduction technique was applied to calculate both the weights and the standard deviations. The correspondence between experimental data and theoretical values was verified by performing and graphing the linear combination of the three appropriately weighted spectra. The correspondence between calculated and experimental spectra was excellent in all cases; an example is given in Fig. 4 for Rosa Limbara. By using the ${ }^{238} \mathrm{U}$ and ${ }^{226}$ Ra mass ratio $\left(U_{\text {nat }}\right.$ ural: ${ }^{226} \mathrm{Ra}=1: 3.376 \times 10^{-7}$ ) [25], the specific activity of ${ }^{226} \mathrm{Ra}$ was also determined.

\subsection{Exposure indexes}

The contribution of building materials to radon exposure can be expressed either as whole-body exposure to gamma radiation or internal dose of inhaled radon [7]. To evaluate the exposure to gamma radiation, which mainly originates from the presence of primordial radionu- 

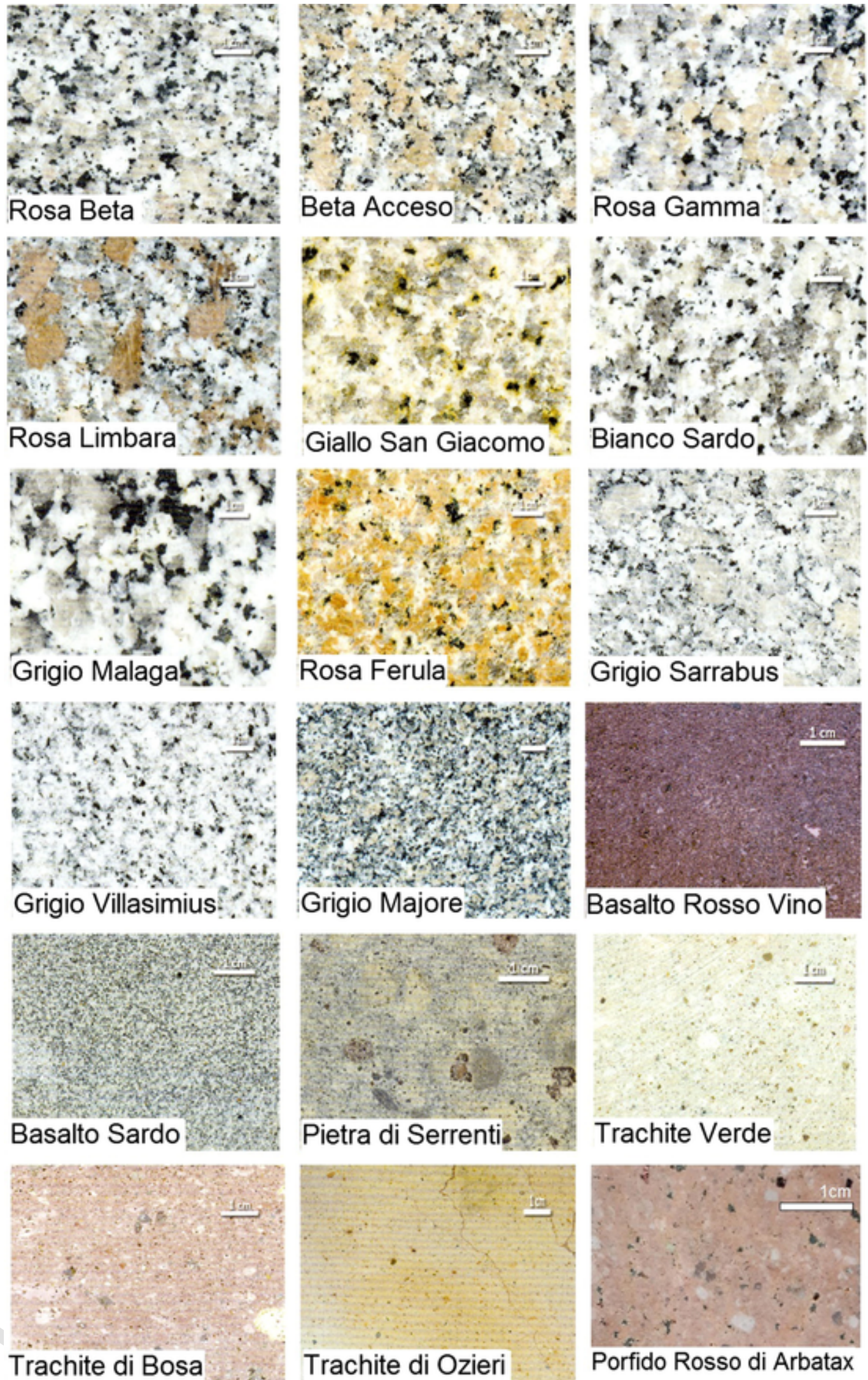

Porfido Rosso di Arbatax

Fig. 1. Sardinian dimension stones tested for radon emission [10]. 
Table 1

Main features and exploiting quarries of tested samples.

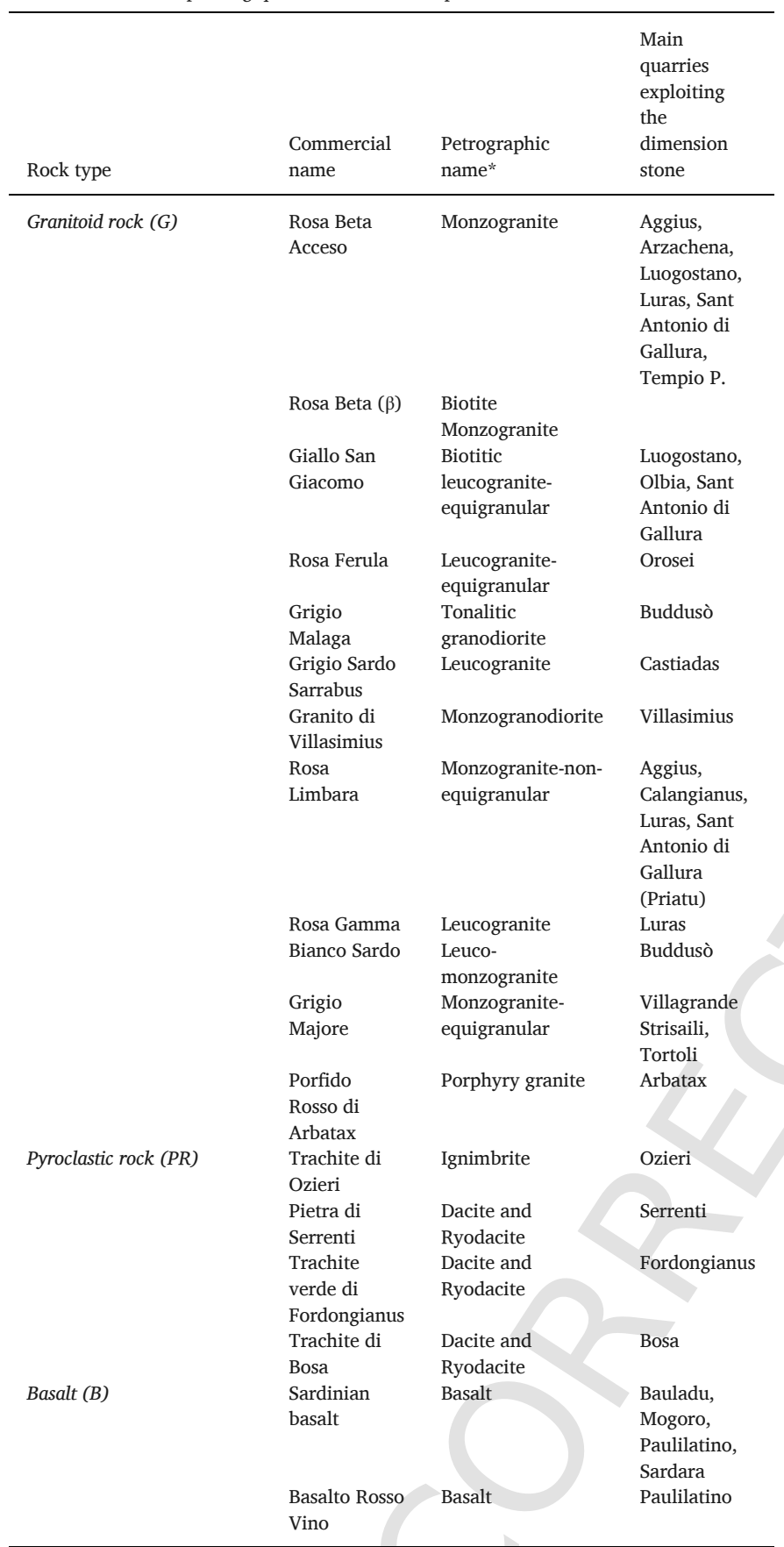

*petrographic classification from $[8 ; 9 ; 14 ; 15]$. where $\mathrm{C}_{\mathrm{Ra}}, \mathrm{C}_{\mathrm{Th}}$ and $\mathrm{C}_{\mathrm{K}}$ are the activity concentration of ${ }^{226} \mathrm{Ra},{ }^{232} \mathrm{Th}$ and ${ }^{40} \mathrm{~K}$ respectively. The building materials should be restricted in their use if their activity concentration index $\mathrm{I}_{\gamma}$ is higher than 1 , which corresponds to an effective annual dose exceeding $1 \mathrm{mSv}$ [26]. However, the limitation only applies to hypothesis of massive use of the indicted material (i.e.: construction of structural walls and/or interior coating of confining surfaces). The $\mathrm{H}_{\mathrm{ex}}$ index must be less than the unity for the radiation hazard to be negligible [28] and $\mathrm{Ra}_{\mathrm{eq}}$ should not exceed the value of $370 \mathrm{~Bq} \mathrm{~kg}{ }^{-1}$ for the material to be used for newly built dwellings and public buildings [29].

\section{Results and discussion}

\subsection{Measurements results and risk indexes}

Table 3 summarizes the test results and the radiological indexes, together with the porosity of each sample. As regards radon exhalation rates, the detected levels were found between the minimum detectable value and a maximum value of $0.92 \pm 0.05 \mathrm{~Bq} \mathrm{~m}^{-2} \mathrm{~h}^{-1}$ (Pietra di Serrenti); the average value was $0.48 \pm 0.29$ (SD). The lowest exhalation rates were estimated for basalts. Although granites gave evidence of a wide variability in the results, higher mean values were generally found for granites compared to other rock types. Among granites, with some exception, higher mean exhalation rates were detected for Leucogranites compared to Monzogranites. The results are comparable to those reported by several authors for rocks of same commercial type or same geological environment $[16,30,31,32]$.

The activity concentration of ${ }^{226} \mathrm{Ra},{ }^{232} \mathrm{Th}$ and ${ }^{40} \mathrm{~K}$ was found consistent with the literature data reported in Table 2 and, specifically, in the range from 3 to $80 \mathrm{~Bq} \mathrm{~kg}^{-1}$ (mean value 29) for ${ }^{226} \mathrm{Ra}$, from 4 to $97 \mathrm{~Bq} \mathrm{~kg}^{-1}$ (mean value 52) for ${ }^{232} \mathrm{Th}$ and from 238 to $1826 \mathrm{~Bq} \mathrm{~kg}^{-1}$ (mean value 1004) for ${ }^{40} \mathrm{~K}$, in. The mean radionuclide concentration of ${ }^{226} \mathrm{Ra}$ and ${ }^{232} \mathrm{Th}$ resulted respectively lower and slightly above the mean reference value of $50 \mathrm{~Bq} \mathrm{~kg}-1$ (both for ${ }^{226} \mathrm{Ra}$ and ${ }^{232} \mathrm{Th}$ ) [33]. The mean activity concentration for ${ }^{40} \mathrm{~K}$ resulted twice the mean reference value of $500 \mathrm{~Bq} \mathrm{~kg}^{-1}$ [33], which may be correlated to high contents of potassium feldspar minerals in the tested samples [15].

In order to assess the radiation hazard both with reference to the whole-body exposure and to radon intake (inhalation and ingestion), the radiological parameters $\mathrm{I}_{\gamma}, \mathrm{H}_{\mathrm{ex}}$ and $\mathrm{Ra}_{\mathrm{eq}}$ were calculated (Table 3): $\mathrm{I}_{\gamma}$ varied between 0.13 and $0.99, \mathrm{H}_{\mathrm{ex}}$ between 0.09 and 0.72 , and $\mathrm{Ra}_{\mathrm{eq}}$ was in the range $33-265 \mathrm{~Bq} \mathrm{~kg}^{-1}$. None of those indexes exceeded the reference limits. The results were found in agreement with previous studies $[14,16,24]$.

Fig. 5 shows the contribution to the $\mathrm{I}_{\gamma}$ index of the radioactivity content for Potassium, Thorium and Radium. The limit of 1 , beyond which the building materials should be restricted in their use, is also reported. Lower value of $I_{\gamma}$ was observed in Basalts and Trachite di Ozieri, while the highest value was in Grigio Majore, Giallo San Giacomo e Rosa Ferula. Major contribution to radioactivity in trachyte and basalts comes from Potassium. In most of granites, Thorium and Potassium contribute for about $50 \%$ each.

\subsection{Correlation between radium content and radon exhalation rate}

Uranium/Radium levels in a given rock depend on its genetic nature, evolution degree and mineralogical composition [3]. The sample with the highest Ra activity concentration was Giallo San Giacomo (Leucogranite), even though the radon exhalation rate was not the highest compared to other samples. This can be explained by taking into account the textural features, fractures and weathering state of the rock $[6,32,34]$, which determine the possibility for radon atoms to escape from the surface of the Ra-bearing minerals or remain trapped within the rock. In fact, when a ${ }^{226} \mathrm{Ra}$ atom decays a $\mathrm{Rn}$ atom is formed together with an alpha particle [3]. The radon atom is ejected from the crystal or molecular lattice in opposite direction to the surface. Based on the recoil energy and its direction, only a fraction of radon atoms escapes from the rock structure [35]. Presence of micro fractures and porous media in the rock structure can facilitate radon escape and increase the probability to reach outside environments $[3,34]$. 

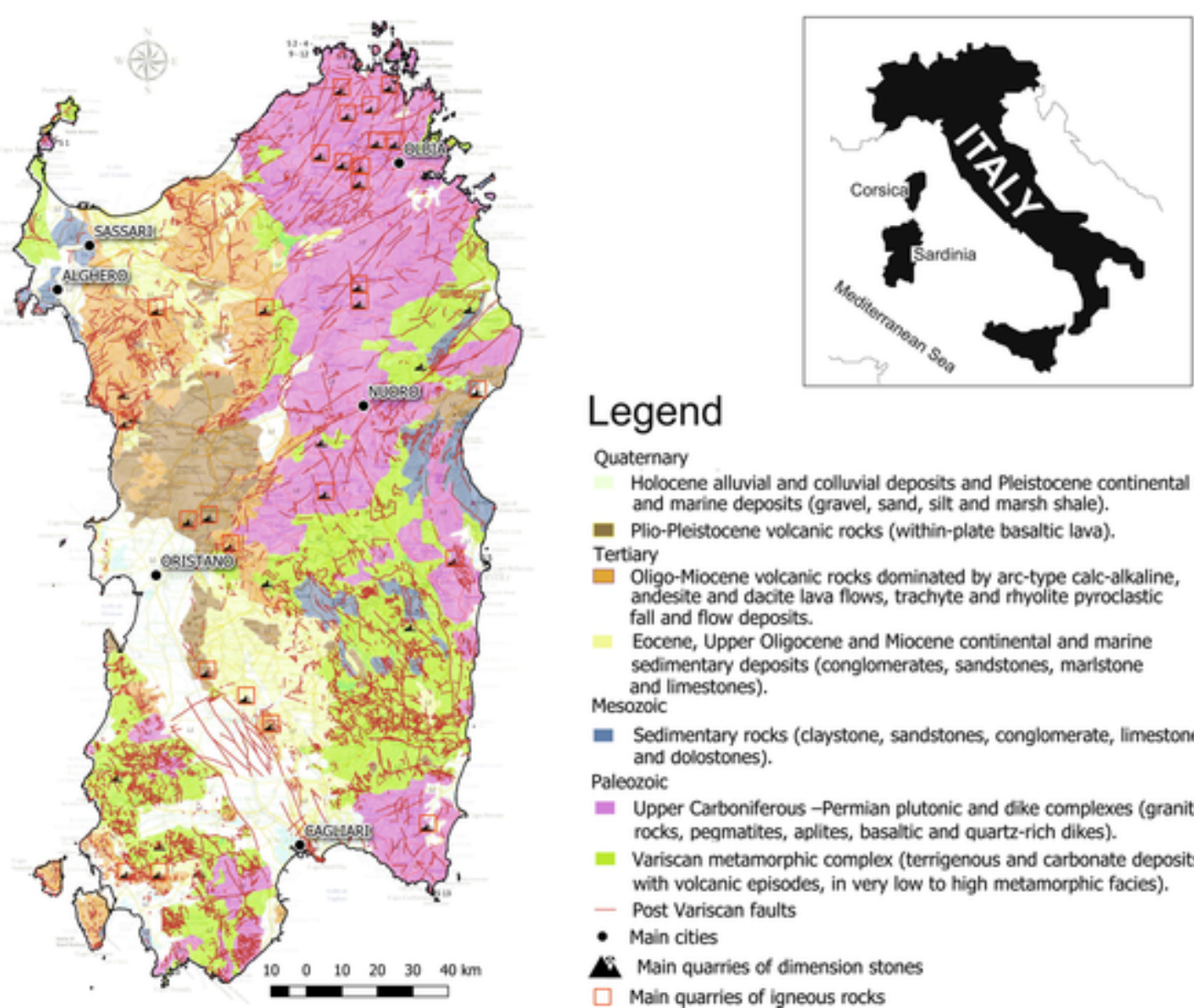

\section{Legend}

\begin{tabular}{l} 
Quaternary \\
Holocene alluvial and colluvial deposits and Pleistocene continental \\
and marine deposits (gravel, sand, silt and marsh shale). \\
Plio-Pleistocene volcanic rocks (within-plate basaltic lava), \\
Tertiary \\
Oligo-Miocene volcanic rocks dominated by arc-type calc-alkaline, \\
andesite and dacite lava flows, trachyte and rhyolite pyroclastic \\
fall and flow deposits. \\
Eocene, Upper Oligocene and Miocene continental and marine \\
sedimentary deposits (conglomerates, sandstones, marlstone \\
and limestones). \\
Mesozoic \\
Sedimentary rocks (claystone, sandstones, conglomerate, limestones \\
and dolostones). \\
Paleozoic \\
Upper Carboniferous -Permian plutonic and dike complexes (granitic \\
rocks, pegmatites, aplites, basaltic and quartz-rich dikes). \\
Variscan metamorphic complex (terrigenous and carbonate deposits \\
with volcanic episodes, in very low to high metamorphic facies). \\
- Post Variscan faults \\
- Main cities \\
\hline Main quarries of dimension stones \\
\hline Main quarries of igneous rocks
\end{tabular}

Fig. 2. Simplified geological map of Sardinia with main quarries of dimension stones, [after 10, modified].

Table 2

Mean values and standard deviation of activity concentration of ${ }^{226} \mathrm{Ra},{ }^{232} \mathrm{Th},{ }^{40} \mathrm{~K}$ published in the literature for the same lithotypes tested in this study.

\begin{tabular}{llllll}
\hline \multirow{2}{*}{ Rock Type } & n. of data & \multicolumn{2}{c}{ Radionuclide Concentration $\left(\mathrm{Bq} \mathrm{kg}^{-1}\right)$} & Refs. \\
\cline { 3 - 5 } & & ${ }^{226} \mathrm{Ra} \pm \sigma$ & ${ }^{232} \mathrm{Th} \pm \sigma$ & ${ }^{40} \mathrm{~K} \pm \sigma$ & \\
\hline Granites & 10 & $41 \pm 17$ & $53 \pm 22$ & $1068 \pm 137$ & {$[16]$} \\
Granites & 17 & $47 \pm 32$ & $66 \pm 33$ & $1013 \pm 215$ & {$[15]$} \\
Granites & 7 & - & $69 \pm 29$ & $1177 \pm 400$ & {$[14]$} \\
Trachytes & 7 & $31 \pm 5$ & $42 \pm 4$ & $1038 \pm 252$ & {$[15]$} \\
Basalts & 6 & $10 \pm 3$ & $14 \pm 4$ & $442 \pm 100$ & {$[15]$} \\
\hline
\end{tabular}

In the case of rock samples Rosa Limbara, Grigio Sardo Sarrabus, Pietra di Serrenti and Porfido Rosso di Arbatax, although the activity concentration of Ra was found not significantly high compared to the other samples, high radon exhalation rates were observed (see also Fig. 6 ). That might depend on the radium distribution within the mineral grains, the texture and size of the grains, the grains permeability [31] and the sample porosity. For example, the Pietra di Serrenti has an activity concentration of ${ }^{226} \mathrm{Ra}$ similar to Rosa Gamma, but the texture of Pietra di Serrenti is porfiric while that of Rosa Gamma is equigranular and holocrystalline, with larger crystals; moreover, the Pietra di Serrenti is hydrothermally alterated and its porosity is about 16 times that of Rosa Gamma. In some samples, a large proportion of Uranium/Radium elements could not be confined to accessory minerals, as a result of the alteration processes that affected the rock [32], so that the daughter nuclides (Rn) can easily get away.

In accordance to other studies [31,32], a poor correlation was found between radon exhalation rate and radium content, as the ac tual rate remains strongly influenced by the rock's physical characteristics (e.g. texture, density, porosity, alteration, etc.) [16,32,36]. Some authors found a better correlation [30], but for exhalation rate lower than $2 \mathrm{~Bq} \mathrm{~m}^{-2} \mathrm{~h}^{-1}$ the relationship $\mathrm{Ra} / \mathrm{Rn}$ becomes more dispersed and the correlation definitely lower.

\subsection{Contribution of building materials to indoor radon concentration}

With the necessary schematic assumptions and based on the results of the radon exhalation test, it is possible to calculate the contribution to indoor radon accumulation of a given stone, hypothetically used to confine a defined volume.

The indoor radon concentration originated from the confining walls can be easily estimated as follows [37]:

$\mathrm{C}_{\mathrm{Rn}}=\mathrm{E}_{\mathrm{Rn}} \mathrm{A}_{\mathrm{r}} / \mathrm{V}_{\mathrm{r}} \lambda_{\mathrm{v}}$

where $A_{r}$ is the area of the wall surface; $V_{r}$ is the volume of the confined space and $\lambda_{\mathrm{v}}$ is the room ventilation rate. The Ratio $A_{r} / V_{r}$ is 1.6, considering a standard room of $4 \times 5 \times 2.8 \mathrm{~m}^{3}$, while the ventilation rate is assumed to be between 0.2 and $2 \mathrm{~h}^{-1}$ [37]. In this study, the highest calculated value of $E_{R n}$ was about $0.92 \mathrm{~Bq} \mathrm{~m}^{-2} \mathrm{~h}^{-1}$ for Pietra di Serrenti. Considering the lowest air ventilation rate $\left(\lambda_{\mathrm{v}}=0.2\right)$, the estimated indoor radon concentration would be about $7.36 \mathrm{~Bq} \mathrm{~m}^{-3}$ (Table 4), thus considerably lower than the recommended level established by EC Directive 2013/59/Euratom (300 $\mathrm{Bq} \mathrm{m}^{-3}$ ).

\section{Conclusion}

In order to contribute to the overall characterization of the dimension stones mostly used in the Sardinian territory and widely exported worldwide, the radon exhalation rates and the natural radioactivity of eighteen selected samples were estimated. 


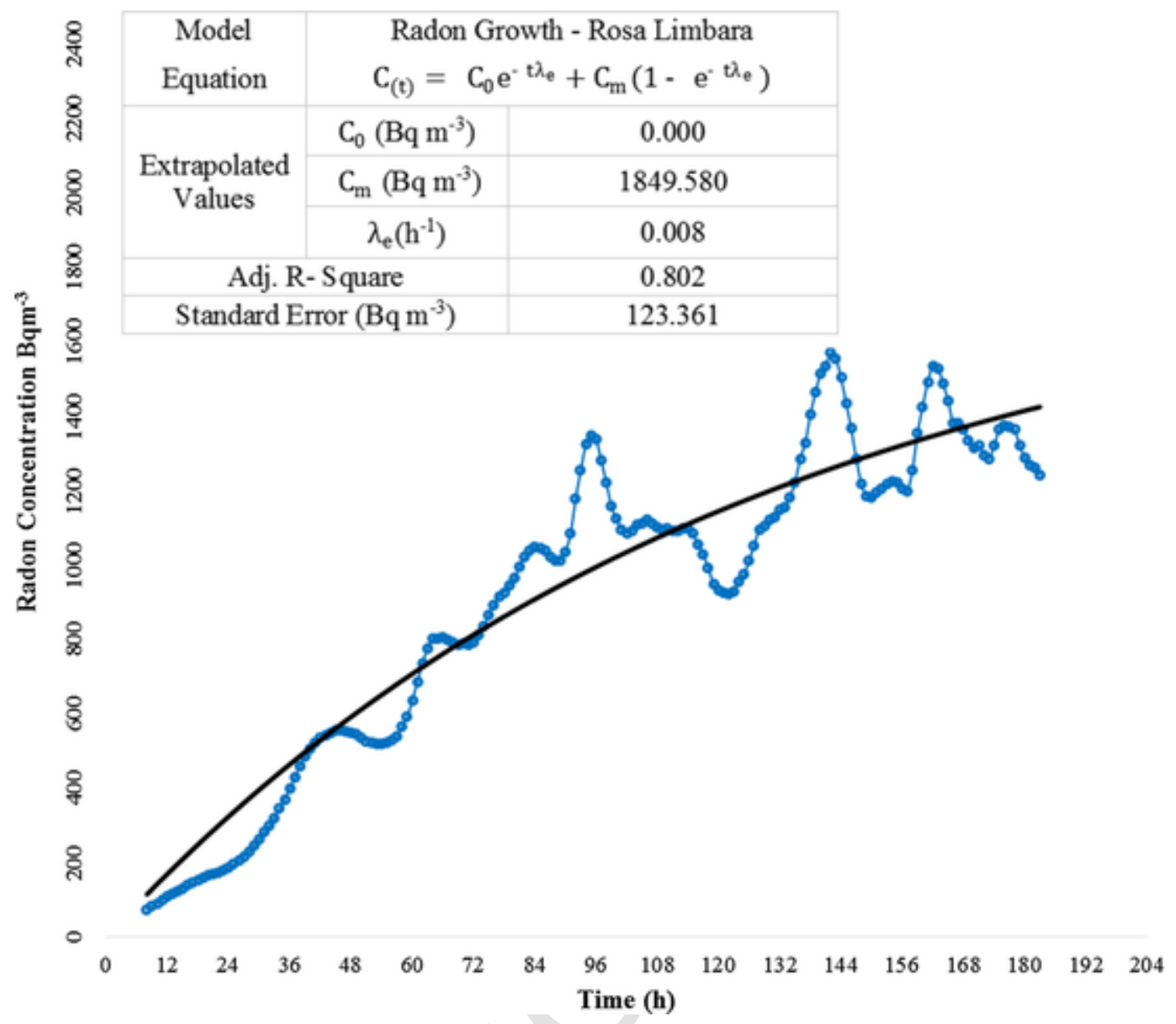

Fig. 3. Radon activity concentration vs. time (Rosa Limbara).

Radon exhalations measurements were performed on the rock slab samples in their natural form, according to the specifications of IAEA (International Atomic Energy Agency). Smaller powdered samples $(100 \mathrm{~g})$ were isolated to determine the content of the natural radionuclides ${ }^{226} \mathrm{Ra}$, ${ }^{232} \mathrm{Th}$, and ${ }^{40} \mathrm{~K}$, by means of gamma-ray spectrometry. The Activity Concentration Index $\left(\mathrm{I}_{\gamma}\right)$ defined by EC-BSS together with the External Radiation Hazard Index (Hex) and the Radium equivalent activity (Raeq) were calculated and found below the reference limits. A comparative analysis of the test results indicates higher levels of ${ }^{226} \mathrm{Ra}$ activity for Giallo San Giacomo, Grigio Majore and Rosa Beta Acceso respectively, whereas higher radon release rates were found for Pietra di Serrenti, Porfido Rosso di Arbatax, Grigio Sardo Sarrabus and Rosa Limbara. The poor correlation between Radon release rate and ${ }^{226} \mathrm{Ra}$ activity concentration was found to be in agreement with previous studies where the radium activity concentration and the exhalation rate of the tested rocks were in the same range as those discussed hereby.

The essential contribution of the stone's physical characteristics in providing radon escape paths from inner rock to surface seemed to be confirmed, even though further investigation must be performed to validate the assumption. The indoor radon accumulation was simulated for a reference room made of Pietra di Serrenti, which showed the higher value of Rn exhalation rate. Despite the hypothesis of poor ventilation, the model proved that radon concentration remains below the reference level of $300 \mathrm{~Bq} / \mathrm{m}^{3}$ established by 2013/59/Euratom Directive, revealing the absence of a substantial risk in dwellings and public buildings where the use of the natural stones under investigation is significant.

\section{CRediT authorship contribution statement}

Valentina Dentoni: Supervision, Conceptualization, Methodology, Formal analysis, Investigation, Writing - original draft, Writing - review \& editing, Data curation, Funding acquisition. Stefania Da Pelo: Supervision, Conceptualization, Methodology, Formal analysis, Investigation, Writing - original draft, Writing - review \& editing, Data curation, Funding acquisition. Mirsina Mousavi Aghdam: Conceptualization, Methodology, Investigation, Data curation, Writing - original draft. Paolo Randaccio: Conceptualization, Investigation, Formal analysis, Data curation. Alfredo Loi: Conceptualization, Methodology, Writing - original draft, Writing - review \& editing. Nicola Careddu: Resources. Alessandra Bernardini: Investigation, Data curation.

\section{Declaration of Competing Interest}

The authors declare that they have no known competing financial interests or personal relationships that could have appeared to influence the work reported in this paper.

\section{Acknowledgements}

Authors are grateful to the Editor and three anonymous Reviewers who contributed to improve the quality of the original manuscript.

This work is part of the research projects funded by Fondazione di Sardegna and Regional Sardinian Government: RE-MINE - REstoration and remediation of abandoned MINE sites, [grant numbeer F72F16003160002] and "Geogenic and anthropogenic sources of minerals and elements: fate and per- 


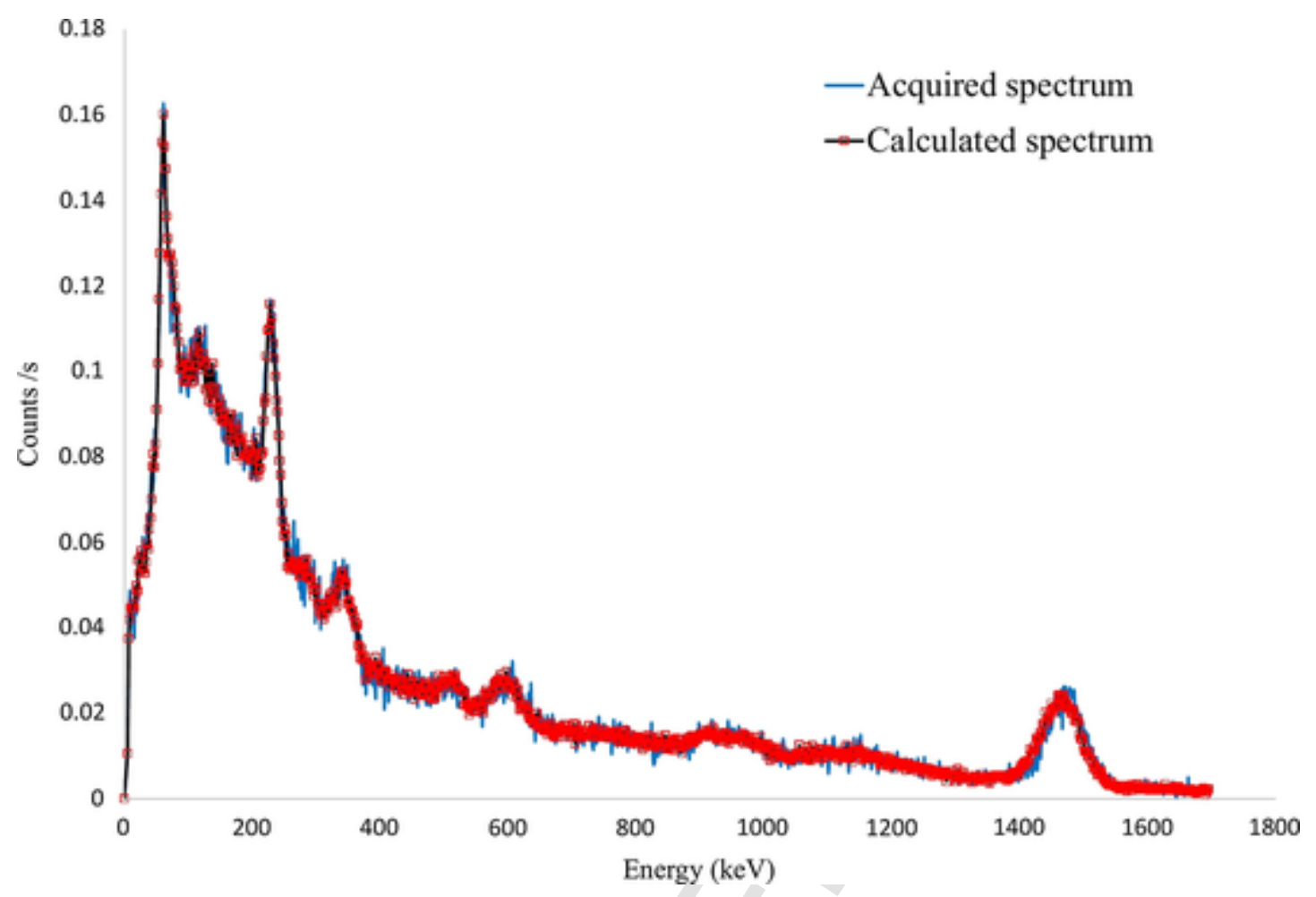

Fig. 4. Comparison of calculated and experimental spectra for Rosa Limbara.

Table 3

Radon exhalation rates, radionuclide contents and radiological indexes.

\begin{tabular}{|c|c|c|c|c|c|c|c|c|}
\hline \multirow[t]{2}{*}{ Sample name } & \multirow[t]{2}{*}{ Porosity } & \multirow{2}{*}{ 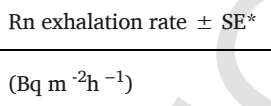 } & \multicolumn{3}{|c|}{ Radionuclide Concentration (Bq kg ${ }^{-1}$ ) } & \multirow[t]{2}{*}{$\mathrm{I}_{\gamma}$} & \multirow[t]{2}{*}{$\mathrm{H}_{\mathrm{ex}}$} & \multirow{2}{*}{$\frac{\mathrm{Ra}_{\mathrm{eq}}}{\left(\mathrm{Bq} \mathrm{kg}^{-1}\right)}$} \\
\hline & & & ${ }^{226} \mathrm{Ra} \pm \sigma^{*}$ & ${ }^{232} \mathrm{Th} \pm \sigma^{*}$ & ${ }^{40} \mathrm{~K} \pm \sigma^{*}$ & & & \\
\hline Rosa Beta Acceso & 0.9 & $0.33 \pm 0.06$ & $46 \pm 2$ & $45 \pm 1$ & $762 \pm 53$ & 0.63 & 0.46 & 169 \\
\hline Rosa Beta $(\beta)$ & 0.8 & $0.108 \pm 0.009$ & $26 \pm 2$ & $55 \pm 2$ & $1049 \pm 57$ & 0.71 & 0.5 & 186 \\
\hline Giallo San Giacomo & 1.3 & $0.39 \pm 0.02$ & $80 \pm 2$ & $73 \pm 1$ & $1057 \pm 48$ & 0.98 & 0.72 & 265 \\
\hline Rosa Ferula & 1.1 & $0.33 \pm 0.03$ & $33 \pm 2$ & $82 \pm 1$ & $1376 \pm 53$ & 0.98 & 0.69 & 257 \\
\hline Grigio Malaga & 0.9 & $0.22 \pm 0.06$ & $18 \pm 2$ & $53 \pm 1$ & $709 \pm 47$ & 0.56 & 0.4 & 149 \\
\hline Grigio Sardo Sarrabus & 0.8 & $0.91 \pm 0.09$ & $35 \pm 2$ & $74 \pm 1$ & $945 \pm 51$ & 0.8 & 0.58 & 214 \\
\hline Granito di Villasimius & 1.0 & $0.1713 \pm 0.0008$ & $23 \pm 2$ & $36 \pm 1$ & $813 \pm 48$ & 0.53 & 0.37 & 137 \\
\hline Rosa Limbara & 1.7 & $0.85 \pm 0.06$ & $25 \pm 2$ & $61 \pm 1$ & $956 \pm 57$ & 0.71 & 0.5 & 186 \\
\hline Rosa Gamma & 0.8 & $0.31 \pm 0.06$ & $31 \pm 2$ & $62 \pm 1$ & $1045 \pm 54$ & 0.76 & 0.54 & 200 \\
\hline Bianco Sardo & 1.2 & $0.59 \pm 0.02$ & $28 \pm 2$ & $97 \pm 1$ & $1078 \pm 55$ & 0.94 & 0.68 & 251 \\
\hline Grigio Majore & 0.8 & $0.68 \pm 0.06$ & $47 \pm 2$ & $86 \pm 1$ & $1206 \pm 54$ & 0.99 & 0.71 & 264 \\
\hline Porfido Rosso di Arbatax & 2.3 & $0.91 \pm 0.09$ & $29 \pm 2$ & $68 \pm 1$ & $1140 \pm 52$ & 0.82 & 0.58 & 214 \\
\hline Trachite di Ozieri & 24.2 & $0.29 \pm 0.04$ & $8 \pm 2$ & $12 \pm 1$ & $238 \pm 54$ & 0.17 & 0.12 & 43 \\
\hline Pietra di Serrenti & 12.9 & $0.92 \pm 0.05$ & $35 \pm 3$ & $41 \pm 2$ & $1778 \pm 72$ & 0.92 & 0.63 & 231 \\
\hline Trachite verde di Fordongianus & 34.0 & $0.26 \pm 0.01$ & $33 \pm 3$ & $42 \pm 2$ & $1826 \pm 59$ & 0.93 & 0.63 & 234 \\
\hline Trachite di Bosa & 12.2 & $0.34 \pm 0.05$ & $20 \pm 2$ & $32 \pm 2$ & $1436 \pm 58$ & 0.71 & 0.48 & 177 \\
\hline Sardinian basalt & 5.7 & ND* & $8 \pm 2$ & $9 \pm 1$ & $345 \pm 50$ & 0.19 & 0.13 & 48 \\
\hline Basalto Rosso Vino & 7.5 & $\mathrm{ND}^{*}$ & $3 \pm 2$ & $4 \pm 1$ & $308 \pm 49$ & 0.13 & 0.09 & 33 \\
\hline
\end{tabular}

$\mathrm{SE}^{*}$ : Standard Error of the Estimated Value, $\sigma^{*}$ : Associated Uncertainty $(1 \sigma), \mathrm{ND}^{*}$ : Not Detectable.

sistency over space and time in sediments" [grant number F74I19000960007]; this project was also funded by Sardegna Ricerche Project "Testare" [grant number F21B17000790005]. 


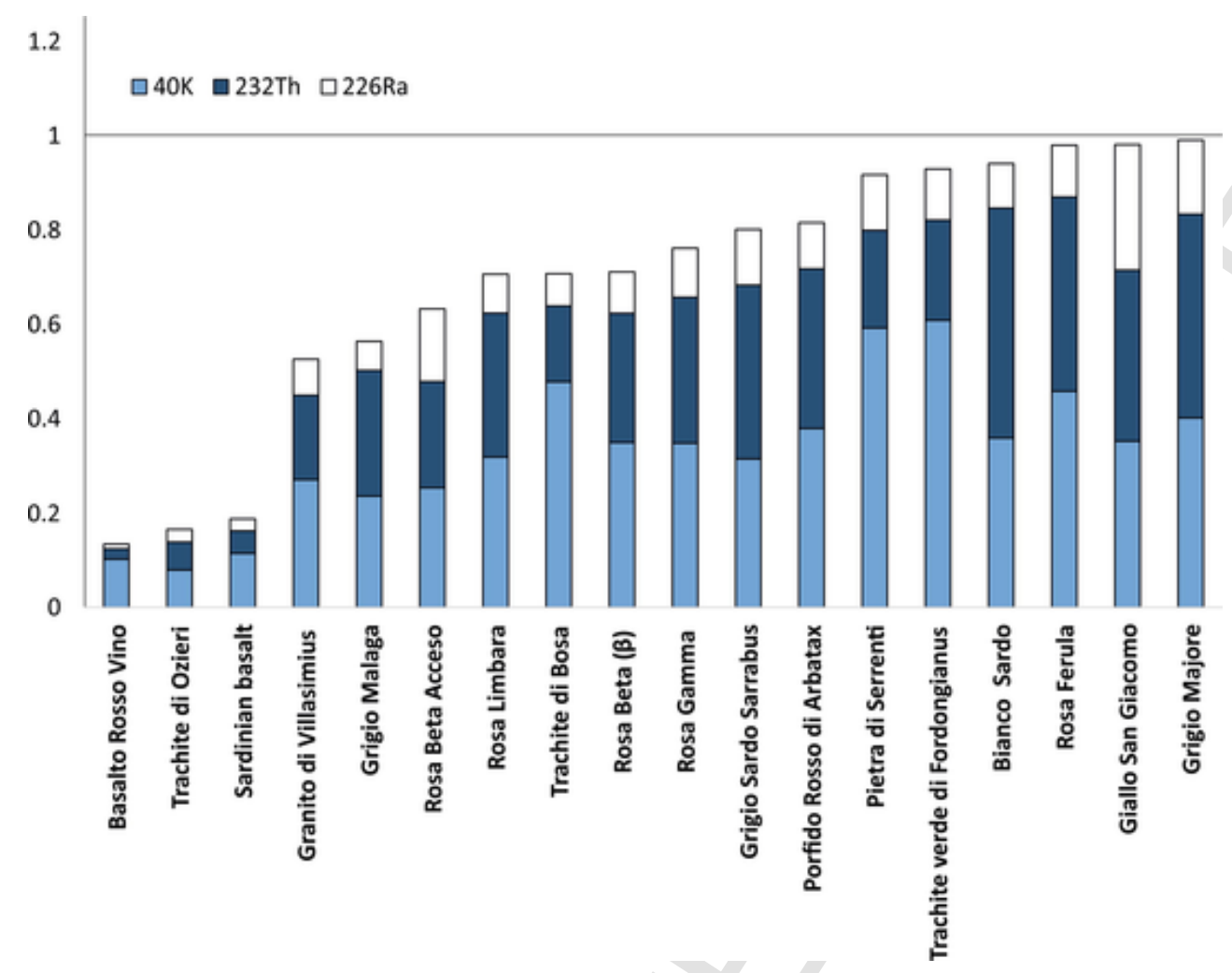

Fig. 5. Contribution to the $I_{\gamma}$ index calculated for each samples of ${ }^{40} \mathrm{~K},{ }^{232} \mathrm{Th}$ and ${ }^{226} \mathrm{Ra}$.

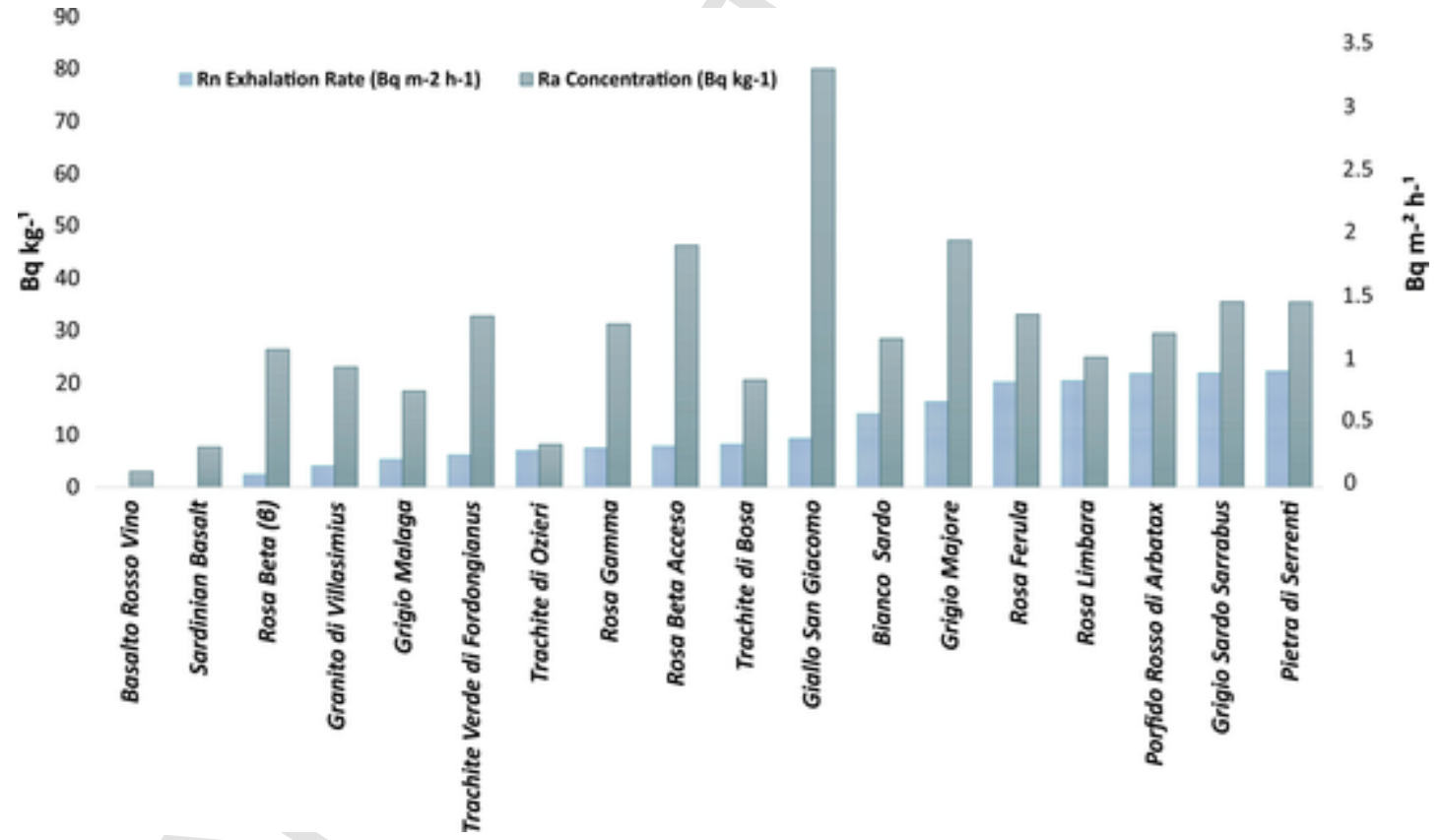

Fig. 6. Radon exhalation rate and radium concentration for each stone sample. 
Table 4

Estimated steady-state radon concentration $\left(\mathrm{Bq} \mathrm{m}^{-3}\right)$ due to radon exhalation from the rocks with highest calculated radon exhalation rate.

\begin{tabular}{|c|c|c|c|c|c|c|c|}
\hline \multirow[t]{2}{*}{ Sample name } & $\begin{array}{l}\text { Test } \\
\text { duration }\end{array}$ & \multicolumn{3}{|c|}{ Recorded radon concentrations } & \multirow{2}{*}{$\begin{array}{l}\text { Estimated } \\
\text { Rn } \\
\text { exhalation } \\
\text { rate }\end{array}$} & \multirow{2}{*}{$\begin{array}{l}\begin{array}{l}\text { Air } \\
\text { exchange } \\
\text { rate }\end{array} \\
\left(\mathrm{h}^{-1}\right)\end{array}$} & \multirow{2}{*}{$\begin{array}{l}\begin{array}{l}\text { Estimated } \\
\text { indoor radon } \\
\text { concentration }\end{array} \\
\left.(\mathrm{Bq} \mathrm{m})^{-3}\right)\end{array}$} \\
\hline & (h) & $\left(\mathrm{Bq} \mathrm{m} \mathrm{m}^{-3}\right)$ & & & & & \\
\hline Pietra di Serrenti & $100 \mathrm{~h}$ & $\begin{array}{l}\text { Minimum } \\
36\end{array}$ & $\begin{array}{l}\text { Maximum } \\
840\end{array}$ & $\begin{array}{l}\text { Average } \\
429\end{array}$ & 0.92 & 0.2 & 7.36 \\
\hline
\end{tabular}

\section{References}

[1] WHO, 2009. World Health Organization. WHO Handbook on Indoor Radon: a Public Health Perspective. WHO Press, Geneva. Available from: http://whqlibdoc.who.int/publications/2009/9789241547673_eng.pdf, (accessed 10 August 2019).

[2] D. Al-Azmi, I.C. Okeyode, O.O. Alatise, A.O. Mustapha, Setup and procedure for routine measurements of radon exhalation rates of building materials, Radiat. Meas. 112 (2018) 6-10, doi:10.1016/j.radmeas.2018.03.001.

[3] P.G.Q. Amaral, T.M.B. Galembeck, D.M. Bonotto, A.C. Artur, Uranium distribution and radon exhalation from Brazilian dimension stones, Appl. Radiat. Isot. 70 (2012) 808-817, doi:10.1016/j.apradiso.2011.10.010.

[4] F. Pertlik, J.J.N. Roger, J.A.S. Adams, Uranium, in: K.H. Wedepohl (Ed.), Handbook of Geochemistry, Springer-Verlag, Berlin, 1974, pp. 11-14.

[5] J. Chen, N.M. Rahman, I.A. Atiya, Radon exhalation from building materials for decorative use, J. Environ. Radioact. 101 (4) (2010) 317-322, doi:10.1016/ j.jenvrad.2010.01.005.

[6] A. Pereira, D. Pereira, L. Neves, M. Peinado, I. Armenteros, Radiological data on building stones from a Spanish region: Castilla y León, Nat. Hazards Earth Syst. Sci. 13 (2013) 3493-3501.

[7] S. Stoulos, M. Manolopoulou, C. Papastefanou, Assessment of natural radiation exposure and radon exhalation from building materials in Greece, J. Environ. Radioact. 69 (3) (2003) 225-240, doi:10.1016/S0265-931X(03)00081-X.

[8] N. Careddu, S. Grillo 2015. Rosa Beta granite (Sardinian pink Granite): A heritage stone of international significance from Italy Geological Society, London, Special Publications, 407, 155-172, 21 May 2014, doi: 10.1144/SP407.1.

[9] Careddu, N., Grillo, S., 2019. Trachites from sardinia: Geoheritage and Current Use Sustainability, 11:13, 3706. doi: 10.3390/su11133706.

[10] Careddu, N., Scanu, M., Desogus, P., 2015. Map of natural stones from Sardinia. Ed. by authors, Cagliari, Italy.

[11] L. Carmignani, G. Oggiano, A. Funedda, P. Conti, S. Pasci, The geological map of Sardinia (Italy) at 1:250,000 scale, J. Map. 12 (5) (2016) 826-835, doi:10.1080/17445647.2015.1084544.

[12] C. Ghezzo, J.B. Orsini, Lineamenti strutturali e composizionalidel batolite ercinico sardo corso in Sardegna, Guida Alla Geologia Del Paleozoico Sardo, Soc Geol Ita, Roma, 1982, pp. 88-102.

[13] J.L. Paquette, R.P. Ménot, C. Pin, J.B. Orsini, Episodic and short-lived granitic pulses in a post-collisional setting: evidence from precise $\mathrm{U}-\mathrm{Pb}$ zircon dating through a crustal cross-section in Corsica, Chem. Geol. 198 (2003) 1-20.

[14] A. Puccini, G. Xhixha, S. Cuccuru, et al., Radiological characterization of granitoid outcrops and dimension stones of the Variscan Corsica-Sardinia Batholith, Environ. Earth Sci. 71 (2014) 393-405, doi:10.1007/s12665-013-2442-8. Sardegna Ricerche. https://www.sardegnaricerche.it/inSardegna Ricerche. https: $/ /$ www.sardegnaricerche.it $/$ in -
dex.php? $x s l=370 \& s=37032 \& v=2 \& c=4184 \& n c=1 \& q r=1 \& q p=2 \& o=1 \& \mathrm{t}=3 \& s c=1 \& f a=1 \& b s c=1$. (accessed 10 August 2019).

[16] G. Carrera, M. Garavaglia, S. Magnoni, G. Valli, R. Vecchi, Natural radioactivity and Radon exhalation in stony materials, J. Environ. Radioactivity 34 (2) (1997) 149-159.

[17] ISRM, 1977. Suggested Methods for Determining Water Content, Porosity, Density, Absorption and Related Properties and Swelling and Slake-Durability Index Properties. 3. Suggested method for porosity/density determination using saturation and buoyancy techniques. In Blue Book: "The Complete ISRM Suggested Methods for Rock Characterization, Testing and Monitoring:1974-2006", Ulusay, R., Hudson, J.A. Eds., 143-151.

[18] F. Leonardi, M. Bonczyk, C.M. Nuccetelli, M.B. Wysocka, B.M. Michalik, M. Ampollini, S. Tonnarini, J. Rubin, K. Niedbalska, R. Trevisi, A study on natural radioactivity and radon exhalation rate in building materials containing norm residues: preliminary results, Constr. Build. Mater. 173 (2018) 172-179, doi:10.1016/j.conbuildmat.2018.03.254.

[19] L. Zhang, X. Lei, Q. Guo, S. Wang, X. Ma, Z. Shi, Accurate measurement of the radon exhalation rate of building materials using the closed chamber method, J. Radiol. Prot. 32 (2018) 315-323, doi:10.1088/0952-4746/32/3/315.

[20] B.K. Sahoo, Y.S. Mayya, Two dimensional diffusion theory of trace gas emission into soil chambers for flux measurements, Agric. For. Meteorol. 150 (2018) 1211-1224, doi:10.1016/j.agrformet.2010.05.009.

[21] G. Kemmer, S. Keller, Nonlinear least-squares data fitting in Excel spreadsheets, J. Nat. Prot. 5 (2) (2010) 267-281, doi:10.1038/nprot.2009.182.

[22] Y. Tan, D. Xiao, Revision for measuring the radon exhalation rate from the medium surface, IEEE Trans. Nucl. Sci. 58 (2011) 209-213, doi:10.1109/ TNS.2010.2090897.

[23] IAEA (International Atomic Energy Agency), 2013. Measurement and calculation of radon releases from NORM residues. Technical Reports Series no 474 . P. Kolarž, Novel method of measurement of radon exhalation from building ma-

[24] S. Ashrafi, O. Jahanbakhsh, Measurement of natural radioactivity of Iranian granite samples using beta-gamma coincidence spectrometer and maximum likelihood method, Environ. Earth Sci. 78 (2019) 437, doi:10.1007/ s12665-019-8434-6.

[25] IAEA (International Atomic Energy Agency), 2003. Guidelines for radioelement Mapping using gamma ray spectrometry data: also as open access e-book. International Atomic Energy Agency (IAEA). Austria. Available from: https://wwwpub.iaea.org/mtcd/publications/pdf/te_1363_web.pdf, (accessed 10 August 2019).

[26] EC (European Commission), 1999. Radiation protection 112-Radiological Protection Principles Concerning the Natural Radioactivity of Building Materials. Directorate-General Environment, Nuclear Safety and Civil Protection.

[27] J. Beretka, P.J. Mathew, Natural radioactivity of Australian building materials, industrial wastes and byproducts, Health Phys. 48 (1985) 87-95, doi:10.1097/ 00004032-198501000-00007.

[28] V.R. Krieger, Radioactivity of construction materials, Betonwerk Fertig. Tech. 47 (1981) 468-473.

[29] United Nations Scientific Committee on the Effects of Atomic Radiation. (2000). Sources and effects of ionizing radiation, ANNEX B, Exposures from natural radiation sources. UNSCEAR 2000 REPORT, New York, 1, 97-99.

[30] M. Al-Jarallah, Radon exhalation from granites used in Saudi Arabia, J. Environ. Radioact. 53 (2000) 91-98.

[31] N.M. Hassan, T. Ishikawa, M. Hosoda, Iwaoka, A. Sorimachi, S.K. Sahoo, M. Janik, C. Kranrod, H. Yonehara, M. Fukushi, S. Tokonami, The effect of water content on the radon emanation coefficient for some building materials used in Japan, Radiat. Measure. 46 (2011) 232-237.

[32] D. Pereira, L. Neves, A. Pereira, M. Peinado, J.A. Blanco, J.J. Tejado, A radiological study of some ornamental stones: bluish granites from Extremadura (Spain), Nat. Hazards Earth Syst. Sci. 12 (2012) 395-401.

[33] United Nations Scientific Committee on the Effects of Atomic Radiation (UNSCEAR), 1993. Sources and effects of ionizing radiation. Report to the General Assembly, with Scientific Annexes. https://www.unscear.org/docs/ publications/1993/UNSCEAR_1993_Report.pdf (accessed 10 August 2019).

[34] S. Cuccuru, L. Casini, G. Oggiano, G.P. Cherchi, Can weathering improve the toughness of a fractured rock? A case study using the San Giacomo granite, Bull. Eng. Geol. Environ. 71 (2012) 557, doi:10.1007/s10064-012-0416-9.

[35] Baskaran, M., 2016. Radon: A Tracer for Geological, Geophysical and Geochemical Studies. Springer, Switzerland. doi: 10.1007/978-3-319-21329-3.

[36] I. Sarrou, I. Pashalidis, Radon exhalation from granite countertops and expected indoor radon levels, J. Radioanal. Nucl. Chem. 311 (2017) 913-916, doi:10.1007/s10967-016-5108-7.

[37] A. Awhida, P. Ujić, I. Vukanac, M. Đurašević, A. Kandić, I. Čeliković, B. Lončar, (EAftals, J. Environ. Radioact. 164 (2016) 337-343, doi:10.1016/ 